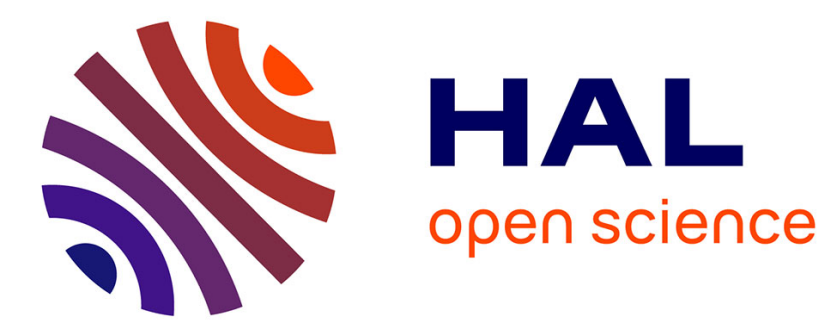

\title{
Extended Administration: Public-Private Management
}

Yacine Bouallouche, Catherine Da Cunha, Raphael Chenouard, Alain Bernard

\section{To cite this version:}

Yacine Bouallouche, Catherine Da Cunha, Raphael Chenouard, Alain Bernard. Extended Administration: Public-Private Management. IFIP International Conference on Advances in Production Management Systems (APMS), Sep 2015, Tokyo, Japan. pp.20-26, 10.1007/978-3-319-22756-6_3 . hal-01417393

\section{HAL Id: hal-01417393 \\ https://hal.science/hal-01417393}

Submitted on 15 Dec 2016

HAL is a multi-disciplinary open access archive for the deposit and dissemination of scientific research documents, whether they are published or not. The documents may come from teaching and research institutions in France or abroad, or from public or private research centers.
L'archive ouverte pluridisciplinaire HAL, est destinée au dépôt et à la diffusion de documents scientifiques de niveau recherche, publiés ou non, émanant des établissements d'enseignement et de recherche français ou étrangers, des laboratoires publics ou privés. 


\title{
Extended Administration: Public-Private Management
}

\author{
Yacine Bouallouche, Catherine da Cunha, Raphael Chenouard, and Alain \\ Bernard \\ LUNAM Universit, Ecole Centrale de Nantes, IRCCyN UMR CNRS 6597, 1 Rue de \\ la Noë, Nantes, FRANCE \\ \{yacine.bouallouche, catherine.da-cunha, \\ raphael.chenouard, alain. bernard\}@ec-nantes.fr
}

\begin{abstract}
In a difficult economic context, the control of public efficiency and the steering of public investment in the private sector are of paramount importance. Here we focus on the evaluation of public-private partnerships efficiency regarding key performance indicators relating to quality of service and financial cost. Computational results on a case study validate the potential of discrete-event simulation for the clothing function in the French army. Initial and final steps are simulated, but also transition steps.
\end{abstract}

Keywords: extended administration, public-private partnership, simulation, network performance

\section{Context}

The economic crisis and the budgetary rigor that followed had many consequences. In Europe it drove the States to diminish their expenses and reduce the number of public servants. Yet one of the levers to boost the economic recovery was to inject public money in sectors that would allow the most pay back in terms of innovation, employment, and public value. Both objectives can be obtained when externalizing previous state realized mission to private tiers. In France the public budget that is re-injected in the private economy to maintain public value mission represents $10 \%$ of global GDP [1]. Furthermore the lever effect is then of 1 to 5 (depending on the sector) [2]. The main challenge is then to use this great opportunity to overcome the economic crisis by optimizing the public-private relationships. The resulting network of actors forms a extended administration

The economic recovery plans are not limited to programs of public work (by nature one-time and limited to construction) but also a real sustainable investment of public found in the private economy. The European Commission [4] proposed 3 indicators to estimate the added value of expenses:

- Do the expenses have a political nature?

- Do tey offer a payback at the European level? 


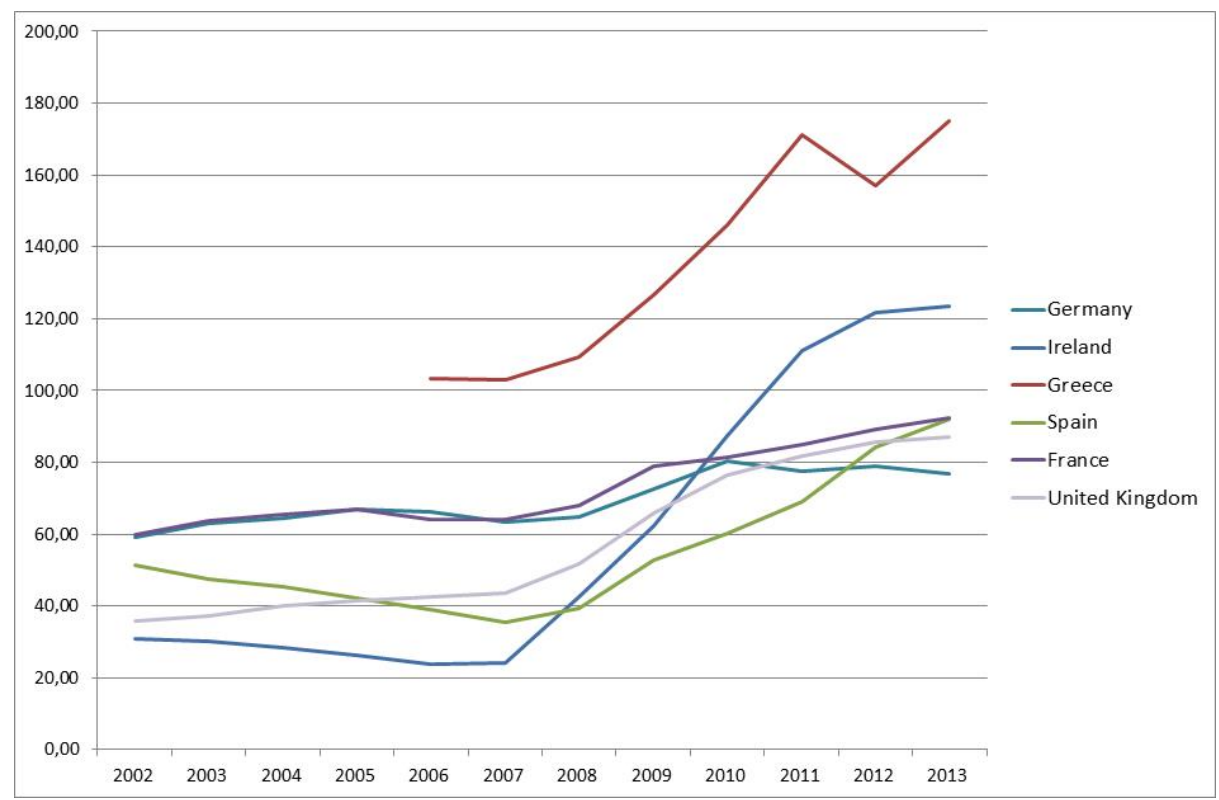

Fig. 1. General government gross debt (Percentage of GDP) [3]

- Do they enable to meet their objective (efficiency)?

In France, a major difficulty is that most investments are done by regions or cities [2]. National directives have little impact, yet a successful example at the national level could play the role of a good practice to follow. Like the Canadian "Program Review" [5] and many other programs conducted by OECD countries and inspired by the New Public Management (NPM) [6], the French General Revision of Public Policies aims at:

- focalizing the State on its sovereign functions,

- doing better and cheaper,

- creating and developing intern and extern providers.

Faced with the limits of the NPM, several countries have begun to amend the reforms inspired by NPM. The French General Revision of Public Policies (GRPP) was deleted and replaced by the Modernization of Public Action (MPA). If the spirit of reform changes, the goal remains the same: reduce the operating costs of administrations. In addition, the MPA has do deal with the legacy of the NPM. The previous reforms have caused fragmentation of public value chains, leaving a legacy of multiple public and private organisms engaged in public services [7]. The production and service networks should combine the strengths of public and private actors to enable the 3 phases of the relationship: shift from public only to private-public partnership (PPP), PPP management but also the destruction of the relationship either to re-integrate the function into the public area or to choose another private provider. 


\section{Definitions and Difficulties}

This context requires the establishment and management of networks to deliver public services. The resulting network of actors forms a extended administration that can relies on the advance made on the extended enterprise domain. A public network is composed of public organizations autonomous in their management although controlled by the state and/or local authorities. In this network, the management of interactions is difficult because its structure is by definition legally "split". The complexity rises in an extended administration because of the inclusion of private organizations. The inclusion of a private organization in a network is described as public-private partnership. The notion of partnership here covers all forms of openings and close links between the public and private sectors. The PPP is a "lasting partnership between legally separate entities pursuing private and public aims and objectives, which, taken separately, could not be achieved with efficiency and economy in the context of programs, projects or operations of general interest, common good or public service" [8]. A literature review and discussions with different actors of the public sectors, we identified three categories of problem with public-private networks

- The public-private partnership performance evaluation;

- The partnership relationship management throughout its life cycle;

- The public-private network management as a whole, to ensure that the local performance is not achieved at the expense of overall performance.

\section{$3 \quad$ Modeling and Managing}

The actual interaction between the State and the potential Private partners takes the form of invitation to tender and corresponding responses. The invitations to tender expose the expectations in term of services and also the contractual commitments in terms of creation of public value (e.g. local supply and employment). The responses present the estimated price and some implementation solutions. Yet as for today there is no tool that enables the quantitative comparison based on objective simulation.

\section{Use Case: Clothing in the French Army}

\subsection{Context}

In France the clothing function for the civil servants represents a market of $650 \mathrm{M} €$ per year, the French army itself stands for $150 \mathrm{M} €$ per year [9]. Table 1 presents some key figures in 2012. 


\begin{tabular}{ll}
\hline Headcount of the users & 300000 \\
Headcount of the public clothing & 1600 people \\
network civil servants & 1300 Full time equivalent \\
Warehouses & 6 in France \\
Defense bases (France \& abroad) & 90 \\
Value of the stocked items & $800 \mathrm{M} €$ \\
\hline
\end{tabular}

Table 1. Key figures in 2012 [10]
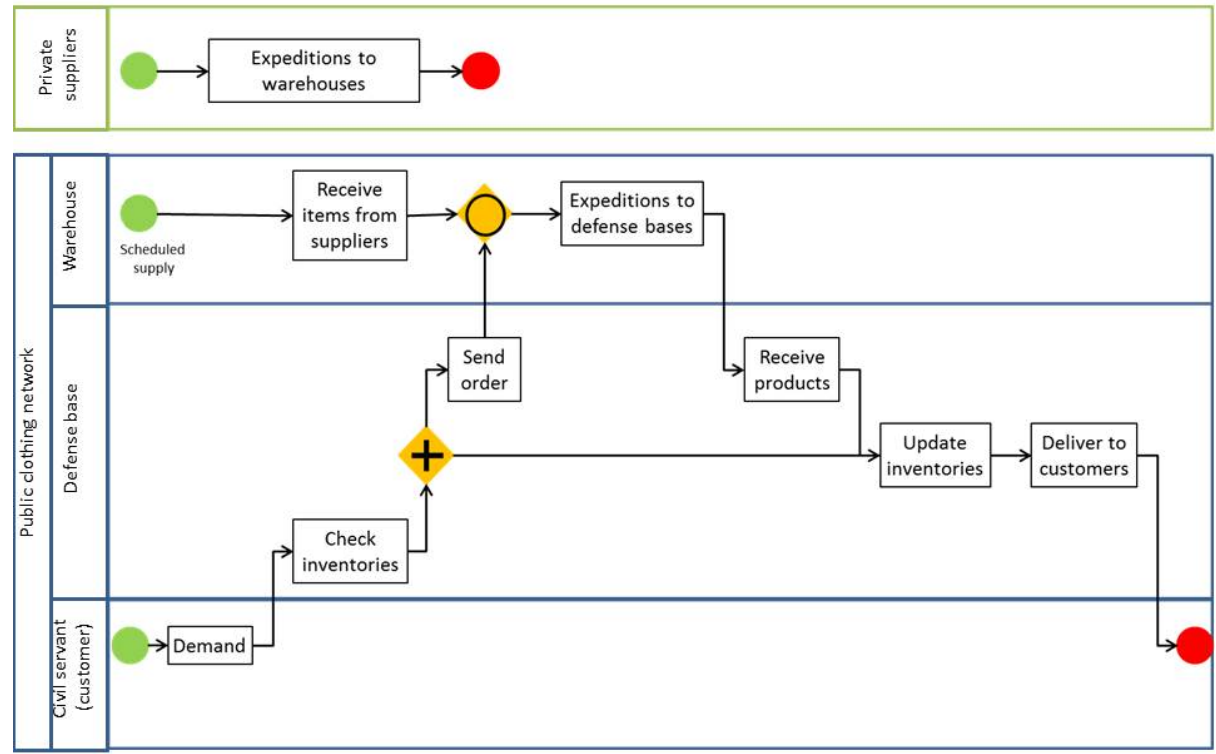

Fig. 2. BPMN diagram for As-Is Modelling

\subsection{As Is Modeling}

Today, the clothing function is operated by public servants see Fig. 2. The procurement is done at a national level, items being furnished by suppliers (often abroad in low cost countries). The replenishment is done on a temporal basis, volumes negotiated for several years based on forecasting.

The storage is done on 6 warehouses, each of them responsible for several defense bases both in France and abroad (in fixed bases and special operations' bases). When a customer (member of the armed force) need an item he/she goes to its defense base supply shop and receive the required item, in the best case immediately and the worst case within days. Local inventories in defenses bases are managed on a base stock policy. 
This operating policy is quite effective on a customer view, level of service and time of service are evaluated as more than satisfying. Yet the operating costs are important (cf. 4.1). The objective of the French government is to reduce both the employment cost and the inventory cost. For instance, there is more than 2 years of inventory held in the 6 warehouses for some items like socks. In this context a proposition is to create a private public network to operate the clothing service.

\subsection{To Be Modeling}

The proposed scenario is to externalize the purchasing and warehousing function for the non-specialized items (high-tech and strategically items such as deminers' vests will remain in the public management). The private provider will manage the interaction with the items' suppliers and answer the demand from the defense bases, see Fig. 3.

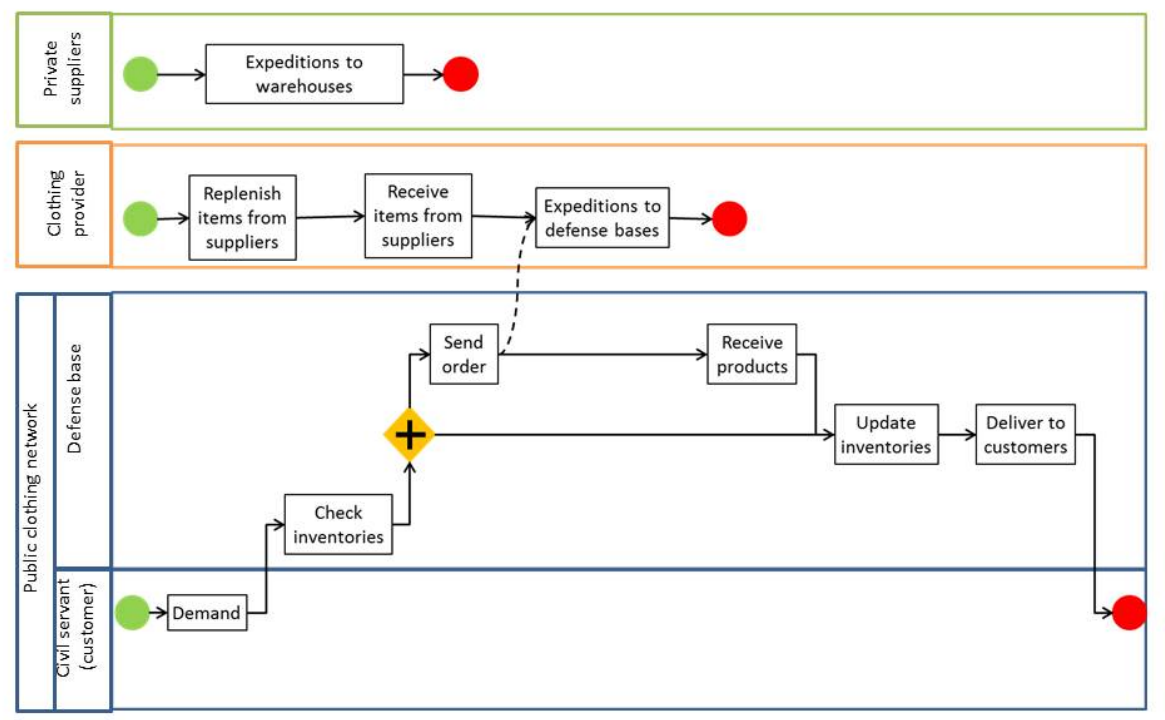

Fig. 3. BPMN diagram for To-Be modelling

The public value generated by the service provider will be guaranteed per contract, with indicators including insertion of disabled employees, employment of target cities inhabitants. 


\subsection{Computational Results}
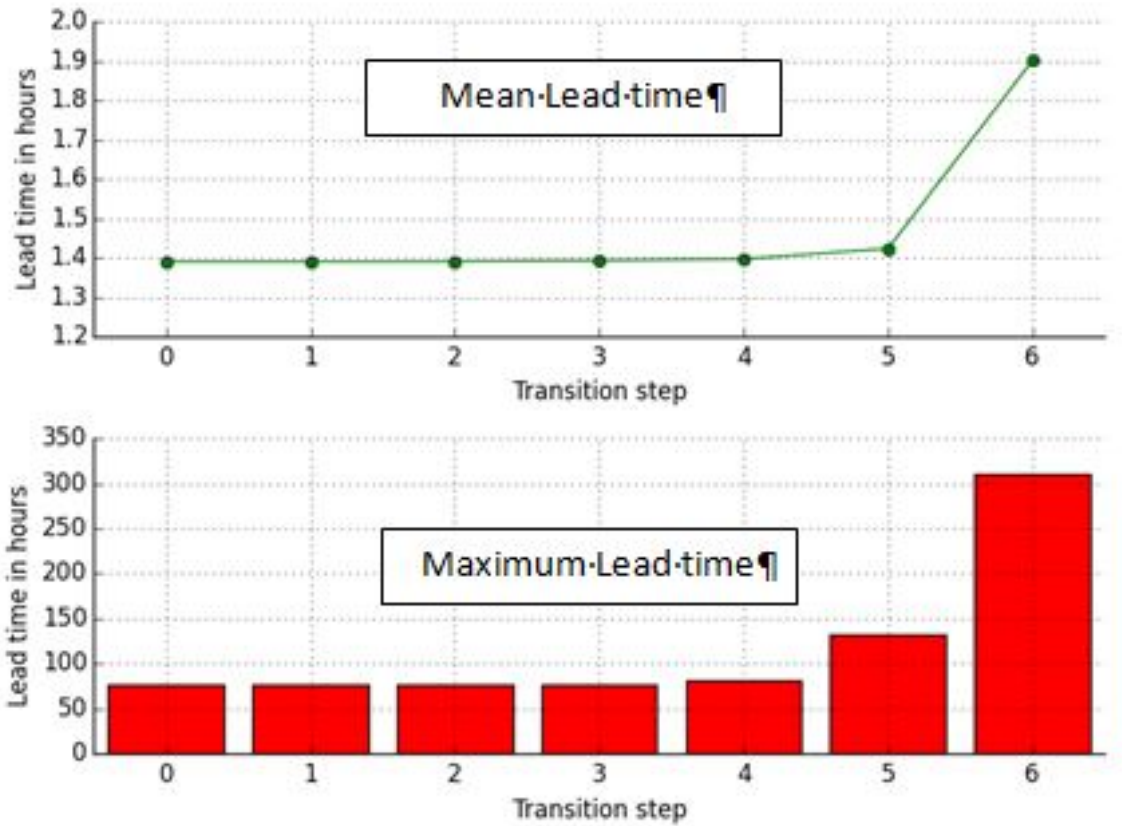

Fig. 4. Simulation results

Using the python SimPy library ${ }^{1}$, we modeled and simulated the As-Is scenario (step 0) and the transition shift to the To-Be PPP (progressive shutting down of the 6 public warehouses: step 1 to 6 ) using discrete event processes. At each transition step, the private provider increases its activity to answer the bases' needs. This modelling aimed at evaluating the impact in terms of service level for the customers (defense civil servants) and eventually re-assess the replenishment policies in the defense bases.

The simulation encompasses the 90 bases and 6 warehouses. The number of items required reaches 2 million for each step, each having a time window of a year.

Figure 4 presents 2 performance indicators: average lead time (curve) and maximal lead time (sticks) for the different steps of the shift. The lead time highlights the quality of service for the army civil servants i.e. the time between the order and the reception of the goods. This time is conditioned not only by the availability of the items but also by the availability of civil servants for the clerical tasks, the packing, the shipping and delivering of the items.

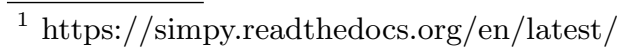


It is interesting to note that if the replenishment policy of the bases remains the same the average lead-time remains acceptable moving form $1.4 \mathrm{~h}$ to $1.9 \mathrm{~h}$. The maximal lead times correspond to a situation when the defense base needs to replenish its stock to answer the civil servant demand. In this case the lead time is multiplied by 4 , but this evolution occurs only in steps 5 and 6 when defense bases abroad shift from public to private provider. The increases is maintained, mostly because to the delivery policy of the PPP agreement, the private partner being committed by contract to ship the items within days of demand reception.

Regarding the HR indicators, the shutting down of public warehouses enable the immediate redeployment of public clothing network civil servants and on the long term their non-replacement.

\section{Conclusion}

The first results presented here enable us to verify that a simulation of a PPP is possible even with little knowledge of the internal private actor activities. The representation of the contractual obligation only permits to obtain KPI for the public service.

This new tool will enable to evaluate objectively and more quantitatively the response to the public invitation to tender. Further research will aim at including more activities to enlarge the evaluation of the private propositions before engaging in a PPP.

\section{References}

1. European Commision: LIVRE VERT sur la modernisation de la politique de l'Union européenne en matière de marchés publics /GREEN PAPER on the modernisation of EU public procurement policy Towards a more efficient European Procurement Market- COM/2011/0015 (2011)

2. Assemblée des communautés de France: Assises de l'investissement : propositions pour un investissement public levier de croissance (2014)

3. Eurostat: http://ec.europa.eu/eurostat, retrieved on April 2015

4. European commission: Reforming the budget, changing Europe - A public consultation paper in view of the 2008/2009 budget (2007)

5. Bourgon J.: Program Review, the Government of Canada's Experience Eliminating the Deficit, 1994-1999: A Canadian Case Study. Centre for international Governance Innovation (2009).

6. Osborne D., Gaeblert T.: Reinventing government: How the entrepreneurial spirit is transforming the public sector. Plume, New York, N.Y. (1993)

7. Lévesque B.: Social In novation in Governance and Public Management Systems: Towards a New Paradigm. In: Moulaert F., McCallum D., Mehhmood A., Hamdouch A. (eds.), Social Innovation: Collective Action, Community Learning and Transdisciplinary Research, Edward Elgar Publishers (2012)

8. Mazouz B., Facal J., Viola J.-M.: Public-private partnership: Elements for a project-based management typology. Project Management Journal, 39 (2), pp. 98-110 (2008) 
9. Ministère Français de l'Economie et des Finances : Guide Gestion de la fonction habillement dans le secteur public-Groupe d'étude des marchés d'habillement et de textile (GEM-HT) (2012)

10. Roger G., Dulait A.: Projet de loi de finances pour 2013 : Défense : préparation et emploi des force, Commission des affaires étrangères, de la défense et des forces armées (2013) 